\title{
Adoption of Internet Banking in Maldives, the Most Important Determinants
}

\author{
Mihna Zahir ${ }^{1} \&$ Behrooz Gharleghi ${ }^{1,2}$ \\ ${ }^{1}$ Faculty of Business and Management, Asia Pacific University of Technology and Innovation, Kuala Lumpur, \\ Malaysia \\ ${ }^{2}$ Centre for the Socio-Economics of Aging (CSEA), Asia Pacific University of Technology and Innovation, \\ Kuala Lumpur, Malaysia \\ Correspondence: Behrooz Gharleghi, Faculty of Business and Management, Asia Pacific University of \\ Technology and Innovation, TPM, 57000, Bukit Jalil, Kuala Lumpur, Malaysia. Tel: 60-19-615-3515. E-mail: \\ behrooz@apu.edu.my
}

Received: August 30, 2014 Accepted: October 10, 2014 Online Published: December 20, 2014

doi:10.5539/ass.v11n2p181 URL: http://dx.doi.org/10.5539/ass.v11n2p181

\begin{abstract}
This research explores the relationship between various variables that may influence the behavioural intention to use internet banking such as social influence, performance expectancy, facilitating conditions, effort expectancy, and trust. One of the main aims of this study is to find out the predictors of internet banking adoption and identify these factors. Further objectives include to investigate whether the independent variables namely performance expectancy, effort expectancy, social influence, facilitating conditions and trust affect the behavioural intention to use internet banking. This study has been conducted in Maldives and it will focus on the internet banking users of central bank of Maldives namely Bank of Maldives. A questionnaire was developed using the variables from UTAUT model with an added variable of trust. A total of 150 respondents were collected using simple random sampling. Regression analysis and Correlation analysis was also carried out to determine the relationships between all the dependant variable and independent variables. The results showed that three variables were found to have less significance to the dependant variable of behavioural intention to use internet banking. These three variables are effort expectancy, social influence and trust.
\end{abstract}

Keywords: effort expectancy, social influence, trust, performance expectancy, facilitating conditions

\section{Introduction}

Numerous researches have been conducted in similar areas by various researchers around the world based on UTAUT model. These researches were mainly carried out in different countries that have different cultures and traditions which maybe the reason for the differences in outcome of study. By finding out the determinants of internet banking adoption, it can help banks in future to develop and enhance their internet banking system. This study focuses on the adoption of Internet banking in the Republic of Maldives. The significance and the motivating factors that lead to internet banking will be assessed and these factors will be further analysed by taking Unified Theory of Acceptance and Use of Technology (UTAUT) model developed by Venkatesh et al. (2003) as a theoretical framework for this research.

In Maldives, even though with the growing trend of technology many individuals are still not using internet banking and opt to go for the traditional retail branch banking. The reasons are unknown to the banks as to why people do not want to adopt internet banking. This remains the case in many other countries as well. Furthermore, not all the banks in Maldives gives customers the choice to use internet banking as a means of making bank transactions and other related services. About almost fifteen years ago, internet was unknown to the major population in the world. Nevertheless, during the turns of the new millennium, numerous websites created and start working (O'Connor \& Galvin, 2001, p. 14). One of new technological advancement in Maldives is the adoption of Internet banking services by major banks. Internet banking is a new concept in Maldives although it has been adopted few years ago and half of the population is yet to adopt this new technology and make the most use of it.

With the increase in technology currently only BML, HSBC, SBI and BOC has adopted Internet banking in 
Maldives. In August 2007, Bank of Maldives launched the Maldives Internet Banking (MIB) service. This service allows customers to pay utility bills and do other related banking transactions through internet (Ibrahim \& Ahmed, 2010). Other banks such as HSBC, SBI and BOC has introduced internet banking services only very recently. Banking via internet is changing lives of people all over the world whereby they can make banking transaction 24 hours a day wherever they are. It has added up to the convenience of adapting to new technologies. Furthermore, it has helped many people who are too busy and have no time to visit traditional bank branches and make transactions. Using internet banking has many advantages for users such as saving time and the accuracy of information flow.

Many of the customers of these banks have registered for internet banking services. However, traditional branch based banking remains as the most used method of making transactions and other related services hence; there are still a large number of current customers who has not adopted internet banking services. They may have many reasons behind not adopting or using internet banking services, but these reasons are unknown to the banks as, so far limited numbers of studies have been done to find out the determinants of internet banking services in Maldives. In order to examine the determinants of Internet banking adoption by individuals, this study will be completed by taking Venkatesh et al. (2003) UTAUT Model as a theoretical Framework. The UTAUT theory mainly explains the user behavioural intention to utilise an information system. It is generally comprises of four variables; namely, effort expectancy, performance expectancy, facilitating conditions, and social influence. This theory developed through a consolidation of the variables of eight models that previous scholars have used to justify the usage behaviour of information systems. Other than these four factors, this study also includes trust as an additional factor to see whether it can affect adoption of internet banking. UTAUT is one of the mostly widely used models among different models used to examine the determinants of computer technology acceptance and utilization among individuals (Venkatesh et al., 2003).

According to the Pikkarainen et al. (2004), the Europe was and it is still the leader in internet banking infrastructure technology and usage. In a comparison study done by Sheshunoff (2000) and Orr (2001), at the end of 2000, almost 20 percent of the banks in USA offered internet banking services and also only 20 percent of the customers in USA private banking equipped with internet connection that used these internet banking services. This number has increased in recent years. However, studies have shown that internet banking acceptance is faced with a lot of challenges and problems. It has been found out that almost half of the people who have decided to adopt and use internet banking services will not turn up as an active users (Robinson, 2000).

Banks all over the world invest a lot of money for online banking systems. Even though millions of dollars have been used in investing and building of online banking systems, literature have revealed that potential users may not utilise the system in spite of accessibility and availability. This condition shows the need for scholars to investigate the factors that determine the acceptance of online banking among users (Wang, Lin, \& Tang, 2003). Maldivian banks also need to identify and study the reasons why most current bank customers has still not accepted and adopted the technology of internet banking.

\section{Literature Review}

\subsection{Internet Banking}

The acceptance of mobile banking has obtained special attention in literature during recent years. Banking specific journals printed special issues on online banking. (Waite \& Harrison, 2002; Karjaluoto et al., 2002; Gerrard \& Cunningham, 2003; Mukherjee \& Nath, 2003). Electronic banking changes the concept of bank's operations by moving the level of banks into different level. E-banking allows customers to conduct their businesses and banking activities in any place and any time. The advantage of internet banking over brick-and-mortar banks is the "timeliness and accuracy of information flow". This reduces the information latency in the environments with intense decision making. (Kesharwani \& Bisht, 2012).

Onar, Aktas and Topcu (2010) applied the multi-criteria decision aid-based (MCDA) model and identify that reliability and security are the two most influential important factors that determines the internet banking adoption in the specific nation. The other determinants found by these authors are socioeconomic class, higher level of education, age, internet accessibility, user friendliness, and finally infrastructural competency that determines the adoption.

\subsection{Performance Expectancy}

Performance expectancy (PE) refers to the degree that people believes that internet banking usage helps to gain profit or save costs when performing online banking tasks (Venkatesh et al., 2003). Performance expectancy also 
reflects the perception of users of performance improvement when using online banking, for example, payment convenience, service effectiveness, and fast responses (Zhou, Lu, \& Wang, 2010). The other determinants in other models that are concerned about performance expectancy are outcome expectancy in SCT model, relative advantage in DOI model, job-fit in MPCU model, extrinsic motivation in MM model, and finally perceived usefulness in TAM model (Al-Qeisi., 2009).

Furthermore, this factor (performance expectancy) has frequently proved to be the strongest determinant (predictor) for behavioural intention (Venkatesh et al., 2003). Previous literature on technology acceptance and use of technology identified that performance expectancy is the major predictor for employee's behavioural intentions towards technology usage (Venkatesh et al., 2012). Yu (2012) conducted a study that utilised the UTAUT model, and found that variable "age" do not moderate the influence of PE to behavioural intention. Nevertheless, statistical figures show that PE is the important factor for people intention for internet banking in all ages. Additionally Yu found that variable "gender" significantly moderate the influence of PE towards behavioural intention of using technology in a way that men perceived more performance expectancy than women.

\subsection{Effort Expectancy}

Effort expectancy (EE) shows the degree for ease of use for online banking and it is equivalent to the perceived ease of use in Technology Adopted Model, and also the complexity in DOI and MPCU models in a way that these models use the same construct (Al-Qeisi, 2009). Based on the UTAUT model, effort expectancy positively affects the performance expectancy. As long as people feel that online banking is convenient and easy to use, it can be conclude that people will have high expectation in achieving the EE (Zhou et al., 2010).

Venkatesh and Zhang (2010) among other literature show that the influence of EE towards behavioural intention is moderated by gender and age. Furthermore, Yu (2012) study shows that the influence of EE towards behavioural intention moderated by age only. The latter study additionally revealed that the influence of EE was significantly amplified by elderly.

\subsection{Social Influence}

Venkatesh et al. (2003) determine the definition of social influence (SI) as the degree that people perceived the importance of using new technology by others believes. This factor reflects the influence of variables such as opinions of family, close friends, and colleagues on user behaviour. This factor is similar to the subjective norms in TRA model. Opinions of people who are close to the user will be taken into account most of the time when they decide to adopt any new technology. Additionally this factor (SI) is represented in literature and exists in other models such as subjective norms in TAM2, TPB, and DTPB models, social factors in MPCU and image in DOI models.

When we do a comparison between these models, it is identified that this variable (SI) is significant in voluntary contexts and it is significant when usage is mandatory. A study done by Im, Hong, and Kang (2011) on international comparison for technology adoption using UTAUT model between USA and Korea shows that after the coefficients of UTAUT model is estimated in both countries, results reveal that all paths were significant in the case of Korea whereas social influence (SI) detect insignificant in the case of USA. This study further reveals no significant difference in the effect of SI between USA and Korea. It is well known that social influence is higher in Asian countries.

\subsection{Facilitating Conditions}

Facilitating condition (FC) refers to the impact of technical and organisational infrastructure to back the usage of online banking that contains user's ability, knowledge, and resources (Venkatesh et al., 2003). This factor is similar to the other constructs in existing models such as perceived behavioural control in TAM, TPB, DTPB, as well as facilitating conditions in MPCU, and compatibility in DOI model. General comparison among these models shows that the relationship between behavioural intention of use and this variable is almost similar in voluntary and mandatory settings.

According to the UTAUT model, facilitating conditions determine technology use. Facilitating conditions is hypothesized in UTAUT model to influence technology use considering the idea that in an organizational environment, facilitating conditions can serve as the proxy for actual behavioural control and influence behaviour directly (Ajzen, 1991). This maybe the case as facilitating conditions such as training, development and support will be freely available within an organization whereas the facilitation within the environment available to each and every consumer maybe very different such as technology, application vendors and so on which is why facilitating conditions will act more like perceived behavioural control in theory of planned 
behaviour (TPB) and influence both intention to use and behaviour (Ajzen, 1991).

\subsection{Trust}

Trust is the main central variable in any economic transaction that is conducted offline in retail stores or online via any website. It is more important and become crucial in online banking transactions (Riegelsberger et al., 2005; Gefen \& Straub, 2004; Pavlou \& Fygenson, 2006; Walczuch \& Lundgren, 2004; Gefen et al., 2003; Harridge-March, 2006). During the past years, the crucial role of initiating, building, and maintaining the trust among the sellers and buyers in online platforms is being recognised for successful electronic commerce in both academic and practitioner communities. Many literatures were conducted to check the role of trust in business to consumer electronic markets all over the world (Grabner-Krauter, 2002).

One of the most important reasons why trust become the most crucial variable when people doing online transactions as compared to offline retail store transactions is the level of uncertainty that comes in the virtual environments. Furthermore, in online based transactions the risk level is higher and they are mostly caused by uncertainty in using technological infrastructures in exchange for information, or it may be further justified by the people who are involved in online transactions (Grabner-Krauter, 2002). In the same area of trust, Tee et al. (2014) show that security and trust is the main determinants of electronic ticketing in airline industries.

\section{Methodology}

The main aim of this study is to realize the main predictors for Internet banking adoption in Maldives by using Venkatesh et al. (2003) UTAUT Model as a theoretical framework. Unified Theory of Acceptance and Use of Technology or UTAUT is one of the most used models in studying user acceptance of information systems all over the world currently. This technique is proposed to determine the user intention to apply any information system that includes the software as well. As an additional variable, trust will be added to this framework.

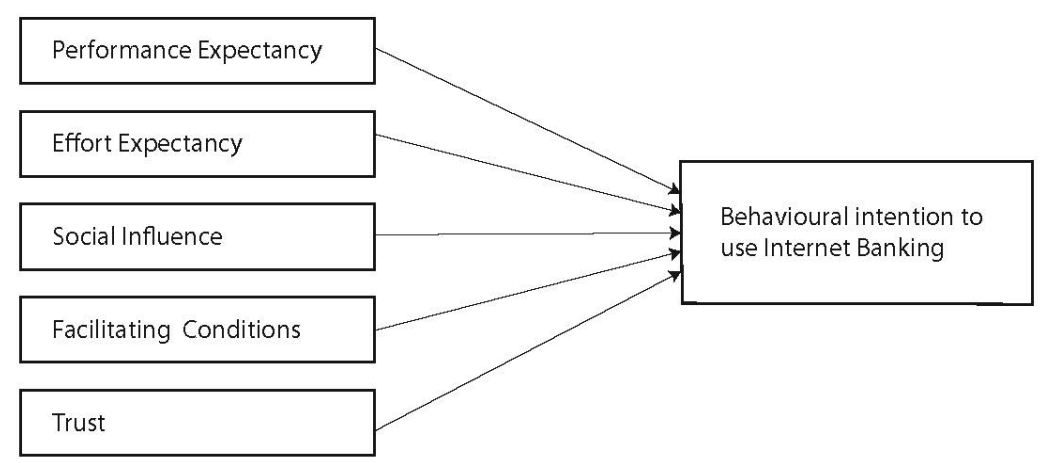

Figure 1. Augmented framework of the UTAUT model

The data collected will be analysed using the Statistical Package for Social Sciences (SPSS for Windows version 19). The main statistical analysis was descriptive statistics which was frequency, percentage, mean and standard deviation that were calculated to examine the respondents' profiles. Furthermore, Test of Pearson moment correlation, ANOVA analysis, and multiple linear regressions were used in this research.

Based on the main objective quoted above, following hypotheses are developed and will be tested in this study, and they are quoted based on alternative hypothesis $\left(\mathrm{H}_{1}\right)$ :

$\mathrm{H}_{1}$ : There is a significant relationship between performance expectancy and behavioural intention to use internet banking.

$\mathrm{H}_{2}$ : There is a significant relationship between effort expectancy and behavioural intention to use internet banking.

$\mathrm{H}_{3}$ : There is a significant relationship between social influence and behavioural intention to use internet banking.

$\mathrm{H}_{4}$ : There is a significant relationship between facilitating conditions and behavioural intention to use internet banking.

$\mathrm{H}_{5}$ : There is a significant relationship between trust and behavioural intention to use internet banking. 


\section{Empirical Findings}

This part also consists of descriptive analysis of respondent's characteristics and information related to variables used in this study. Reliability tests has been carried out to determine the internal consistency of variables, followed by ANOVA tables to check the overall relationship between all the independent variables and the dependant variable followed by correlation tests to test the hypothesis and lastly multiple regression tests has been carried out to test the hypothesis.

\subsection{General Analysis of Responses}

First part of the questionnaire includes basic characteristics of the respondents which includes variables such as gender, age, marital status, educational background, occupation and whether they use BML internet banking or not. Following is the breakdown of the variables for the 150 questionnaires that were responded.

Table 1. Overall frequency table

\begin{tabular}{lll}
\hline Variables & Frequency (n) & Percentage (\%) \\
\hline Gender & & \\
Male & 85 & 56.7 \\
Female & 65 & 43.3 \\
Age & & \\
$19-24$ & 48 & 32.0 \\
$25-35$ & 63 & 42.0 \\
$36-45$ & 27 & 18.0 \\
Above 45 & 12 & 8.0 \\
Marital Status & & \\
Single & 61 & 40.7 \\
Married & 64 & 42.7 \\
Divorced & 24 & 16.0 \\
Widowed & 1 & 0.7 \\
Educational Background & & \\
Below O'level & 21 & 14.0 \\
A'level & 38 & 25.3 \\
Professional Certificate & 28 & 18.7 \\
Undergraduate & 40 & 26.7 \\
Masters & 19 & 12.7 \\
Doctorate & 4 & 2.7 \\
Occupation & & \\
Employed & 103 & 68.7 \\
Self-employed & 24 & 16.0 \\
Homemaker & 3 & 2.0 \\
Student & 20 & 13.3 \\
\hline & &
\end{tabular}

\subsection{Reliability Statistics}

In order to further test the internal consistency of the variables, Cronbach's alpha has been used as illustrated in Table 2. Cronbach's alpha is defined as a coefficient of reliability (Faed, 2013). For a reliability test to be valid the value of Cronbach's alpha should be 0.7 or higher. The reliability test conducted on 23 variables present in the questionnaire yielded a Cronbach's alpha of 0.871 which is essentially higher than the recommended minimum figure of 0.7 thus, it can be concluded that there is a high level of reliability or internal constituency.

Table 2. Reliability statistics

\begin{tabular}{lll}
\hline Cronbach's Alpha & Cronbach's Alpha Based on Standardized Items & No of Items \\
\hline 0.871 & 0.870 & 23 \\
\hline
\end{tabular}




\subsection{Correlation of Variables}

In order to reflect the strength of the relationship between the frequencies of dependant variable and independent variables, Pearson correlation was computed. Pearson correlation measures the linear association between two metric variables where the number representing the Pearson correlation is referred to as a correlation coefficient (Hair et al., 2011). According to Kimmel and Oliver (2006), Pearson moment correlation is the most frequently used method of correlation which measures whether the variables have a positive or negative relationship. All the values calculated have been interpreted using the value interpretation in Table 3.

Table 3. Value interpretation table for correlation

\begin{tabular}{ll}
\hline$r$ value & Interpretation \\
\hline $\mathbf{r}=\mathbf{0}$ & No correlation \\
$\mathbf{0 . 1} \leq \mathbf{r} \leq \mathbf{0 . 3}$ & Very weak correlation \\
$\mathbf{0 . 3 1} \leq \mathbf{r} \leq \mathbf{0 . 4 9}$ & Weak correlation \\
$\mathbf{0 . 5} \leq \mathbf{r} \leq \mathbf{0 . 6 5}$ & Moderate correlation \\
$\mathbf{0 . 6 6} \leq \mathbf{r} \leq \mathbf{0 . 7 9}$ & High correlation \\
$\mathbf{0 . 8} \leq \mathbf{r} \leq \mathbf{0 . 9 9}$ & Very high correlation \\
$\mathbf{r}=\mathbf{1}$ & Perfect correlation \\
\hline
\end{tabular}

Table 4. Correlation coefficients and significant level

\begin{tabular}{lllllll}
\hline & & $\begin{array}{l}\text { Performance } \\
\text { Expectancy }\end{array}$ & $\begin{array}{l}\text { Effort } \\
\text { Expectancy }\end{array}$ & $\begin{array}{l}\text { Social } \\
\text { Influence }\end{array}$ & $\begin{array}{l}\text { Facilitating } \\
\text { Conditions }\end{array}$ & Trust \\
\hline \multirow{3}{*}{$\begin{array}{l}\text { Behavioural Intention } \\
\text { to use Internet Banking }\end{array}$} & $\begin{array}{l}\text { Pearson } \\
\text { Correlation }\end{array}$ & $0.605^{*}$ & $0.542^{*}$ & -0.004 & $0.594^{*}$ & $0.294^{*}$ \\
& Sig. (2-tailed) & 0.000 & 0.000 & 0.961 & 0.000 & 0.000 \\
& $\mathrm{~N}$ & 150 & 150 & 150 & 150 & 150 \\
\hline
\end{tabular}

Table 5. Overall correlations between dependant and independent variables

\begin{tabular}{llll}
\hline Relationship of each IV with DV & r value & interpretation \\
\hline $\begin{array}{l}\text { Behavioural intention to use internet banking and } \\
\text { performance expectancy }\end{array}$ & 0.605 & Moderate positive relationship \\
$\begin{array}{l}\text { Behavioural intention to use internet banking and effort } \\
\text { expectancy }\end{array}$ & 0.542 & $\begin{array}{l}\text { Moderate positive relationship } \\
\begin{array}{l}\text { Behavioural intention to use internet banking and social } \\
\text { influence }\end{array}\end{array}-0.004$ & $\begin{array}{l}\text { Very weak negative to almost no } \\
\text { relationship }\end{array}$ \\
$\begin{array}{l}\text { Behavioural intention to use internet banking and facilitating } \\
\text { conditions }\end{array}$ & 0.594 & Moderate positive relationship \\
Behavioural intention to use internet banking and trust & 0.294 & Weak positive relationship \\
\hline
\end{tabular}

Based on the overall Pearson correlation coefficients, the results indicate that, performance expectancy, effort expectancy and facilitating conditions has moderate positive relationship whereas trust has weak positive relationship and social influence has very weak negative relationship towards the dependant variable (behavioural intention to use internet banking). Among all the variables, performance expectancy has the most significant correlation with behavioural intention to use internet banking.

\subsection{Hypothesis Testing Using Multiple Regression}

Since correlation analysis do not provide enough information to make a proper decision regarding the relationships between the variables, multiple regression has been used to test the hypothesis for the independent and dependant variables. Multiple regression analysis which is also an extension of simple linear regression is used to predict the value of a variable based on the value of two or more variables. It allows determining the overall fit of the model and overall contribution of each predictor to total variance explained. Hypothesis testing for this study will be by using alternative hypothesis $\left(\mathrm{H}_{1}\right)$ of all the variables which shows that there is a 
significant relationship between the independent and dependant variable. The table below shows the result generated from multiple regression for the study.

Table 6. Multiple regression results

\begin{tabular}{lllll}
\hline & Coefficients & Std. error & t-stat & Sig. \\
\hline Performance Expectancy & $\mathbf{0 . 3 2 9}$ & $\mathbf{0 . 0 6 1}$ & $\mathbf{5 . 3 8 7}$ & $\mathbf{0 . 0 0 0}$ \\
Effort Expectancy & -0.019 & 0.075 & -0.255 & 0.799 \\
Social Influence & 0.053 & 0.073 & 0.726 & 0.469 \\
Facilitating Conditions & $\mathbf{0 . 3 2 6}$ & $\mathbf{0 . 0 6 7}$ & $\mathbf{4 . 8 8 2}$ & $\mathbf{0 . 0 0 0}$ \\
Trust & -0.058 & 0.081 & -0.720 & 0.473 \\
\hline
\end{tabular}

According to the data analysed and as per table 6, it can be found out that performance expectancy is the strongest predictor of behavioural intention to use internet banking which also coincides with Venkatesh et al. (2003) view expressed in literature review. Based on the hypothesis testing in table 6, since p-value (0.000) is less than 0.05 , proving that hypothesis $\mathrm{H}_{1}$ is accepted indicating there is a significant relationship between behavioural intention to use internet banking and performance expectancy. Studies conducted by Sok and Yin-Fah (2011), also supports the facts confirmed by the researcher in the hypothesis testing for the variable performance expectancy where it was found out that there was a significant relationship between performance expectancy and behavioural intention.

Based on the hypothesis testing in table 6 , since p-value $(0.799)$ is greater than 0.05 , proving that second hypothesis is rejected indicating that there is no significant relationship between behavioural intention to use internet banking and effort expectancy. The data presented earlier in this chapter support the hypothesis testing of this study as it confirms that effort expectancy does not have a direct effect on behavioural intention to use internet banking but has an indirect effect on user adoption through expected performance. Similar conclusion has been come up with Zhou and Lu et al. (2010) in their study.

Table 7. Summary of hypothesis testing

\begin{tabular}{|c|c|c|c|}
\hline Hypothesis Statement & Findings & & Results \\
\hline $\begin{array}{l}\text { There is a significant relationship between behavioural intention to use } \\
\text { internet banking and performance expectancy }\end{array}$ & $\begin{array}{l}P \quad(0.000) \\
0.05\end{array}$ & $<$ & $\begin{array}{l}\text { The hypothesis is } \\
\text { accepted }\end{array}$ \\
\hline $\begin{array}{l}\text { There is a significant relationship between behavioural intention to use } \\
\text { internet banking and effort expectancy }\end{array}$ & $\begin{array}{l}P(0.799) \\
0.05\end{array}$ & $>$ & $\begin{array}{l}\text { The hypothesis is } \\
\text { rejected }\end{array}$ \\
\hline $\begin{array}{l}\text { There is a significant relationship between behavioural intention to use } \\
\text { internet banking and social influence }\end{array}$ & $\begin{array}{l}P \quad(0.469) \\
0.05\end{array}$ & $>$ & $\begin{array}{l}\text { The hypothesis is } \\
\text { rejected }\end{array}$ \\
\hline $\begin{array}{l}\text { There is a significant relationship between behavioural intention to use } \\
\text { internet banking and facilitating conditions }\end{array}$ & $\begin{array}{l}P \quad(0.000) \\
0.05\end{array}$ & $<$ & $\begin{array}{l}\text { The hypothesis is } \\
\text { accepted }\end{array}$ \\
\hline $\begin{array}{l}\text { There is a significant relationship between behavioural intention to use } \\
\text { internet banking and trust }\end{array}$ & $\begin{array}{l}P(0.473) \\
0.05\end{array}$ & $>$ & $\begin{array}{l}\text { The hypothesis is } \\
\text { rejected }\end{array}$ \\
\hline
\end{tabular}

Based on the hypothesis testing in table 6 , since p-value $(0.469)$ is greater than 0.05 , proving that third hypothesis is rejected indicating there is no significant relationship between behavioural intention to use internet banking and social influence. This regression partially answers research objective number 3 of investigating whether social influence can affect behavioural intention to use internet banking. Therefore, it has been proved that social influence does not affect behavioural intention to use internet banking achieving the third objective of this research. This correlation can further be proved using the study conducted by Al-Qeisi (2009) reviewed in the literature.

Based on the hypotheses testing in table 6 , since p-value $(0.0000)$ is less than 0.05 , proving that fourth hypothesis is accepted, indicating that there is a significant relationship between behavioural intention to use internet banking and facilitating conditions. This regression partially answers research objective number 4 of investigating whether facilitating conditions can affect behavioural intention to use internet banking. Therefore, it has been proved that facilitating condition affects behavioural intention to use internet banking achieving the 
fourth objective of the research. This regression testing can further be proved using the study of Yu (2012) reviewed in the literature quoting that facilitating conditions was found out to have a higher effect on males compared to females.

Finally, the p-value for trust $(0.473)$ which is higher than 0.05 , indicate that the fifth hypothesis is rejected, meaning there is no significant relationship between trust and behavioural intention to use internet banking. Although this is the case in Maldives, there were some countries that have experienced people adopting internet banking by taking trust as an important factor. Research carried out by Flavain et al. (2006) shows that trust is considered as one of the main reasons customers are reluctant in adopting internet banking as mentioned in the literature.

Table 7 illustrates the five hypotheses generated from the multiple regression analysis for this study.

\section{Conclusion}

Realizing the main predictors for internet banking is very vital for banks and is helpful for users as well hence this research sought to find out some determinants of internet banking adoption in Maldives with the use of UTAUT model. Through this research it has been found out that performance expectancy and facilitating conditions influence the behavioural intention of using internet banking whereas effort expectancy, social influence and trust does not affect behavioural intention to use internet banking. Like every study, this study also leaves some limitations and gaps that can be filled by further research. The findings of this research will contribute greatly to Bank of Maldives and the banking industry of Maldives and will help to develop and improve internet banking in the country.

\section{References}

Ajzen, I. (1991). The theory of planned behaviour. Organizational Behaviour and Human Decision Processes, 50, 179-211. http://dx.doi.org/10.1016/0749-5978(91)90020-T

Al-Qeisi, K. I. (2009). Analyzing the use of UTAUT model in explaining an online behaviour: Internet banking adoption. Brunel University Brunel Business School PhD Theses.

Faed, A. (2013). An intelligent customer complaint management system with application to the transport and logistics industry (1st ed.). Cham: Springer. http://dx.doi.org/10.1007/978-3-319-00324-5

Flavian, C., Guinaliu, M., \& Torres, E. (2006). How bricks-and-mortar attributes affect online banking adoption. International Journal of Bank Marketing, 24(6), 406-423. http://dx.doi.org/10.1108/02652320610701735

Gefen, D., \& Straub, D. W. (2004). Consumer trust in B2C e-commerce and the importance of social presence: Experiments in e-products and e-services. Omega, 32(6), 407-424. http://dx.doi.org/10.1016/j.omega.2004. 01.006

Gefen, D., Karahanna, E., \& Straub, D. W. (2003). Trust and TAM in online shopping: An integrated model. MIS quarterly, 27(1), 51-90.

Gerrard, P., \& Cunningham, J. (2003). The diffusion of Internet Banking among Singapore Consumers. International Journal of Bank Marketing, 21(1), 16-28. http://dx.doi.org/10.1108/02652320310457776

Grabner-Krauter, S. (2002). The role of consumers' trust in online-shopping. Journal of Business Ethics, 39(1-2), 43-50. http://dx.doi.org/10.1023/A:1016323815802

Hair, J., Celsi, M., Money, A., Samouel, P., \& Page, M. (2011). Essentials of Business Research Methods (1st ed., pp. 352-353). New York City: M.E. Sharpe.

Harridge-March, S. (2006). Can the building of trust overcome consumer perceived risk online? Marketing Intelligence \& Planning, 24(7), 746-761. http://dx.doi.org/10.1108/02634500610711897

Im, I., Hong, S., \& Kang, M. S. (2011). An international comparison of technology adoption: Testing the UTAUT model. Information \& Management, 48(1), 1-8. http://dx.doi.org/10.1016/j.im.2010.09.001

Karjaluoto, H., Mattila, M., \& Pento, T. (2002). Electronic banking in Finland-consumer beliefs and reactions to a new delivery channel. Journal of Financial Services Marketing, 6(4), 346-361. http://dx.doi.org/10.1057/ palgrave.fsm.4770064

Kesharwani, A., \& Bisht, S. S. (2012). The impact of trust and perceived risk on internet banking adoption in India-An extension of technology acceptance model. International Journal of Bank Marketing, 30(4), 303-322. http://dx.doi.org/10.1108/02652321211236923

Kimmel, A., \& Oliver, B. (2006). DNA microarrays (1st ed.). Amsterdam: Elsevier/Academic Press. 
Mukherjee, A., \& Nath, P. (2003). A model of trust in online relationship banking. The International Journal of Bank Marketing, 21(1), 5-15. http://dx.doi.org/10.1108/02652320310457767

O'Connor, J., \& Galvin, E. (2001). Marketing in the Digital Age (2nd ed.). Pearson Education Limited, Essex.

Onar, S. C., Aktas, E., \& Topcu, Y. I. (2010). A Multi-Criteria Evaluation of Factors Affecting Internet Banking in Turkey. Multiple Criteria Decision Making for Sustainable Energy and Transportation Systems. Lecture Notes in Economics and Mathematical Systems, 634, 235-246. http://dx.doi.org/10.1007/978-3-642-040450_20

Orr, B. (2001). E-banking: what next? ABA Banking Journal, 40-46.

Pavlou, P. A., \& Fygenson, M. (2006). Understanding and predicting electronic commerce adoption: An extension of the theory of planned behavior. MIS quarterly, 115-143.

Pikkarainen, T., Pikkarainen, K., Karjaluoto, H., \& Pahnila, S. (2004). Consumer acceptance of online banking: An extension of the technology acceptance model. Internet Research, 14(3), 224-235. http://dx.doi.org/10. $1108 / 10662240410542652$

Riegelsberger, J., Sasse, M. A., \& Mccarthy, J. D. (2005). The mechanics of trust: A framework for research and design. International Journal of Human-Computer Studies, 62(3), 381-422. http://dx.doi.org/10.1016/j. ijhcs.2005.01.001

Robinson, T. (2000). Internet banking: Still not a perfect marriage (pp. 104-106). Informationweek.com.

Sheshunoff, A. (2000). Internet banking-an update from the frontlines. ABA Banking Journal, 51-53.

Sok Foon, Y., \& Fah, B. Y. (2011). Internet Banking Adoption in Kuala Lumpur: An Application of UTAUT Model. International Journal of Business and Management, 6(4), 161-167. http://dx.doi.org/10.5539/ ijbm.v6n4p161

Tee, P. K., Gharleghi, B., Chan, Y. F. B., \& Lim, M. K. (2014). Electronic Ticketing in Airline Industries among Malaysians; the Determinants. International Journal of Business and Social Science, 5(9).

Venkatesh, V., \& Zhang, X. (2010). Unified Theory of Acceptance and Use of Technology: US Vs. China. Journal of Global Information Technology Management, 13(1). http://dx.doi.org/10.1080/1097198X.2010. 10856507

Venkatesh, V., Morris, M. G., Davis, G. B., \& Davis, F. D. (2003). User acceptance of information technology: Toward a unified view. MIS quarterly, 425-478.

Venkatesh, V., Thong, J., \& Xu, X. (2012). Consumer acceptance and use of information technology: Extending the unified theory of acceptance and use of technology. MIS quarterly, 36(1), 157-178.

Waite, K., \& Harrison, T. (2002). Consumer expectations of online information provided by bank websites. Journal of Financial Services Marketing, 6(4), 309-322. http://dx.doi.org/10.1057/palgrave.fsm.4770061

Walczuch, R., \& Lundgren, H. (2004). Psychological antecedents of institution-based consumer trust in e-retailing. Information \& Management, 42(1), 159-177. http://dx.doi.org/10.1016/j.im.2003.12.009

Wang, Y., Wang, Y., Lin, H., \& Tang, T. (2003). Determinants of User acceptance of Internet Banking: An Empirical Study. International Journal of Service Industry Management, 14(5), 501-519. http://dx.doi. org $/ 10.1108 / 09564230310500192$

Yu, C. (2012). Factors Affecting Individuals to Adopt Mobile Banking: Empirical Evidence from the UTAUT Model. Journal of Electronic Commerce Research, 13(2), 104-121.

Zhou, T., Lu, Y., \& Wang, B. (2010). Integrating TTF and UTAUT to explain mobile banking user adoption. Computers in Human Behavior, 26(4), 760-767. http://dx.doi.org/10.1016/j.chb.2010.01.013

\section{Copyrights}

Copyright for this article is retained by the author(s), with first publication rights granted to the journal.

This is an open-access article distributed under the terms and conditions of the Creative Commons Attribution license (http://creativecommons.org/licenses/by/3.0/). 